\title{
Устойчивость крахмала картофеля отечественной селекции
}

\author{
Л.М. Гвоздева*, В.К. Хлесткин \\ ФИЦ Институт ичитологии и генетики СО РАН, Новосибирск, Россия \\ *e-mail: ungersy@mail.ru
}

Картофель (Solanum tuberosum L.) является значимой сельскохозяйственной культурой, а получение картофельного крахмала с заданными свойствами важно и актуально как для его промышленной переработки (перевариваемый крахмал), так и для разработки диет (устойчивый к перевариванию в тонком кишечнике крахмал) для снижения/поддержания веса и для лечения/профилактики ряда заболеваний (сахарный диабет, болезнь Бехтерева, болезнь Крона, ожирение и др.). В отличие от обычного, перевариваемого крахмала, устойчивый крахмал питает полезную микрофлору кишечника, снижает гликемический индекс, повышает чувствительность к инсулину, увеличивает поглощение кальция и железа и способствует выделению гормонов, уменьшающих аппетит.

Из 90 сортов и гибридов картофеля из коллекции «ГенАгро» ФИЦ ИЦиГ СО РАН получены образцы крахмала, которые были исследованы на устойчивость к перевариванию ферментом $\alpha$-амилазой. Выявлены контрастные формы с низкой (40-52\%) и высокой (до 99 \%) устойчивостью.

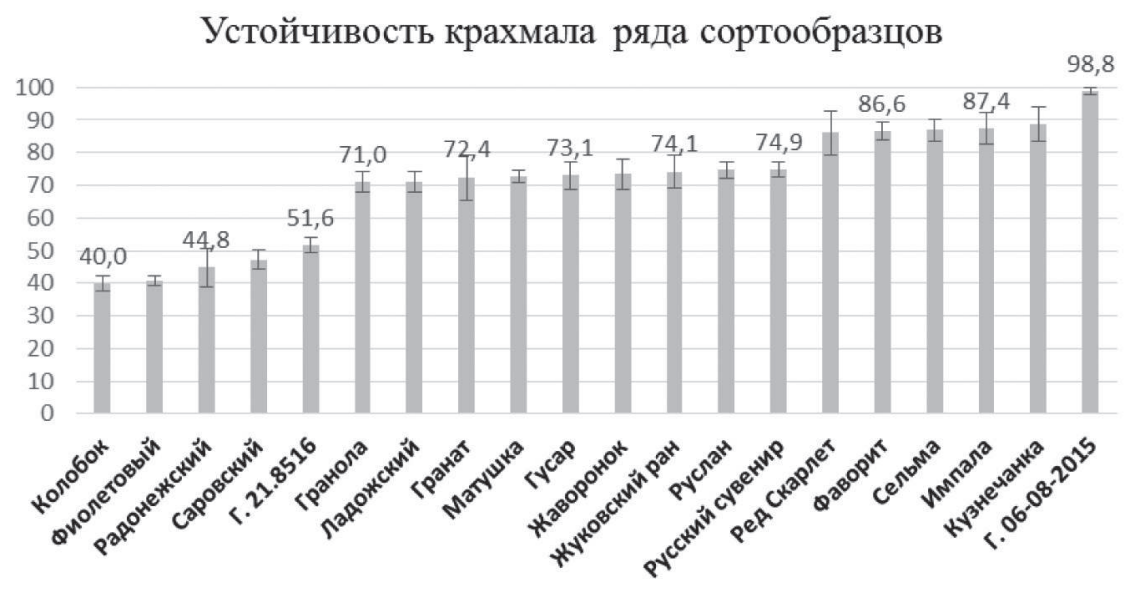

Из клубней тех же сортов была выделена ДНК для SNP-генотипирования, необходимого для дальнейшего полногеномного анализа ассоциаций «генотипфенотип» (GWAS). Генотипирование проводилось на SNP-чипе (22K) третьей стороной (Гатерслебен, Германия). Следующим этапом исследования будет идентификация локусов и сцепленных с ними ДНК-маркеров устойчивости крахмала к перевариванию.

На основании полученных результатов будут разработаны молекулярные маркеры для дальнейшего использования в маркер-ориентированной селекции картофеля с разной усвояемостью крахмала.

Благодарности: Работа выполнена при финансовой поддержке гранта РФФИ № 17-29-08006. 